La radio ha quedado postergada respecto del deporte, pero se ha reinventado en los teléfonos inteligentes o en las computadoras

Matías Canillán

Question/Cuestión, Vol. 2, №66, Agosto 2020

ISSN 1669-6581

https://perio.unlp.edu.ar/ojs/index.php/question/index

IICom-FPyCS-UNLP

\section{LA RADIO HA QUEDADO POSTERGADA RESPECTO DEL DEPORTE, PERO SE HA REINVENTADO EN LOS TELÉFONOS INTELIGENTES O COMPUTADORAS}

\section{THE RADIO HAS BEEN DELAYED WITH RESPECT TO THE SPORT, BUT HAS REINVENTED ITSELF ON SMARTPHONES OR COMPUTERS}

\section{Matías Canillán}

Estudió periodismo deportivo en el Círculo de Periodistas Deportivos. En 2001 ingresó al equipo de deportes de Víctor Hugo Morales en Radio Continental. También trabajó en proyectos en Rock \& Pop, 360TV, HBO y teleSUR. Actualmente es docente en la FPyCS - UNPLP, y trabaja en

Relatores y en Mediapro. matiascanillan@hotmail.com

Twitter: @matiascanillan 


\section{Resumen}

Matías Canillán afirma que el periodista deportivo debe revisar su actualidad y recuperar un lugar central en la radio. Es necesario reconstituirse más sólido, para intervenir en el medio más fiel que cumple 100 años.

\section{Palabras clave}

Radio, Periodista Deportivo, Prestigio

\section{Abstract}

Matías Canillán affirms that sports journalists must review their present and regain a central place on the radio. It is necessary to reconstitute themselves more solid to intervene in the most faithful media (the radio) that is 100 years old.

\section{Key Words}

Radio, Sports journalist, Prestige

\section{ENLACE}

https://go.ivoox.com/rf/55559107 